\title{
THE EFFECT OF THE SKILLS TRAINING METHODS FOREHAND IN THE GAME OF SQUASH STUDENT FIK UNM MAKASSAR
}

\author{
Irvan, Djen Djalal, Iskandar
}

\author{
Correspondence: Fakultas Ilmu Keolahragaan, Universitas Negeri Makassar, \\ Makasar, Indonesia \\ E-mail: irvansir@yahoo.com
}

\begin{abstract}
This study aims to determine the effect of training methods to the skills in the game of squash forehand UNM students FIK Makassar. This study used an experimental method. Subject of this research is the son of FIK UNM students who have not programmed squash courses, majors Penjaskesrek 2016/2017 school year as many as 96 people. Data collection techniques by observation and testing skills forehand in the game of squash. Data analysis techniques used in this research is descriptive and inferential using t-test. Based on the results of the research concluded that: (1) Method of exercise alone has an influence on the skills forehand in the game of squash Students FIK UNM Makassar, (2) Method of exercise in pairs have an influence on the skills forehand in the game of squash Students FIK UNM Makassar, (3) the method of training three people had an influence on the skills in the game of squash forehand FIK UNM Student Makassar, and (4) There are differences between his own training methods, exercises in pairs and methods of exercise three to skills in the game of squash forehand FIK UNM Student Makassar.
\end{abstract}

\section{Keywords: Method Exercise Forehand of Squash}

\section{Pendahuluan}

Cabang olahraga squash adalah olahraga permainan yang dimainkan oleh dua orang dengan menggunakan raket dan sebuah bola kecil di dalam suatu ruangan yang terbatas dan atau di kelilingi oleh dinding. Tujuan permainan ini adalah seorang pemain berusaha memukul bola ke dinding depan dengan sedemikian rupa sehingga lawan tidak dapat dan sulit mengembalikan bola dari lawan. Rahmani menjelaskan bahwa, olahraga squash dimainkan hampir sama dengan olahraga tenis, memukul bola dengan menggunakan sebuah raket. Perbedaannya adalah jika tenis memantulkan dari pemukul bola satu yang berada di depan pemukul lainnya, sedangkan pada olahraga squash bola dipantulkan dengan cara dipukulkan kearah tembok. Pantulan dari tembok ini akan diterima oleh lawan lainnya yang berdiri di sampingnya.

Salah satu wadah pembinaan/pemassalan untuk cabang olahraga berada pada tingkat atau jenjang sekolah maupun kampus. Oleh sebab penjaringan atlet untuk 
cabang olahraga squash di Sulawesi Selatan hanya bersandar pada Fakultas Ilmu keolahragaan, hal inilah yang menyebabkan salah satu faktor prestasi cabang olahraga squash di Sulawesi Selatan tidak mengalami perkembangan yang signifikan.

Peningkatan prestasi squash di Sulawesi Selatan dapat dikembangkan dengan meningkatkan minat atau ketertarikan mahasiswa untuk memprogramkan mata kuliah squash, sebagai mata kuliah pilihan yang nantinya dapat dikuasai sebagai cabang olahraga pilihan yang bukan saja dijadikan sebagai pelengkap pemenuhan SKS dalam penyelesaian studi, akan tetapi sebagai cabang olahraga pilihan untuk prestasi, khususnya dalam upaya peningkatan prestasi squash di Sulawesi Selatan.

Untuk meningkatkan prestasi cabang olahraga squash, mahasiswa harus menguasai keterampilan teknik dasar olahraga squash. Beberapa teknik dasar tersebut adalah pukulan drive, servis, voli, boast, lob, drop shot dan sebagainya. Penguasaan keterampilan teknik dasar ini harus dilatih sesuai dengan program latihan dengan pemberian bentuk metode latihan yang dilakukan secara berkesinambungan.

Squash biasanya di mainkan untuk dua pemain, meskipun ada nomor ganda yang dimainkan di lapangan yang lebih besar. Pertandingan adalah yang terbaik dari tiga set atau lima set pada tingkat internasional. Seorang pemain menang dalam sebuah permainan dengan menjadi yang pertama untuk mencetak baik sembilan poin atau sebelas poin, tergantung pada sistem penilaian - poin atau reli - yang dimainkan. Lawan bergantian memukul bola, yang mungkin menyentuh lantai hanya sekali antara setiap stroke. Bola dapat dipukul dari sisi samping ke dinding depan dan kembali di bawah garis keluar, dan harus memantul dari dinding depan di atas kepingan logam yang dikenal sebagai timah. Kindersley (2013: 196) mengatakan bahwa, karena ukuran kecil dari lapangan squash, pemain sering mendapatkan masalah selama pertandingan, misalnya tabrakan antara pemain dapat terjadi merupakan hal yang umum selama pertandingan. Sedangkan Hirst (2014: 43) menjelaskan bahwa, squash adalah olahraga dimana situasi dan atau lingkungan kita selalu berubah. Ketika pemain baik menyerang bola, sebuah skenario yang sama sekali berbeda tercipta tergantung pada lintasan, kecepatan dan arah bola.

Untuk menguasai teknik dasar keterampilan pukulan forehand, maka dapat dilakukan dengan beberapa metode latihan diantaranya adalah metode latihan sendiri (solo drills), metode latihan berpasangan (pair drills) dan metode latihan tiga orang (three person drills). Ketiga metode latihan ini akan sangat membantu mahasiswa agar bisa menguasai teknik keterampilan pukulan forehand. Selain itu kondisi fisik sangat menunjang penampilan seseorang dalam suatu latihan ataupun pertandingan, salah satunya adalah kemampuan koordinasi mata tangan. Sebab koordinasi mata tangan yang baik akan memberikan kontribusi yang baik pula terhadap keterampilan pukulan forehand. Banyak metode latihan yang sudah diterapkan untuk mengembangkan teknik pukulan forehand, namun masih belum memperhatikan cara yang tepat dan dapat menghasilkan pukulan forehand yang baik. Oleh karena itu berdasarkan asumsi di atas diperlukan suatu jawaban terhadap permasalahan yang telah dipaparkan sebelumnya, sehingga harus ada kajian lebih dalam melalui 
penelitian. Dengan demikian peneliti ingin mengetahui keterampilan pukulan forehand dalam permainan squash Mahasiswa FIK-UNM Makassar.

Penelitian ini bertujuan untuk mengetahui perbedaan hasil keterampilan pukulan forehand bagi yang dilatih menggunakan metode latihan sendiri, metode latihan berpasangan dan metode latihan tiga orang, pada mahasiswa Fakultas Ilmu Keolahragaan Universitas Negeri Makassar. Secara operasional tujuan penelitian ini adalah untuk mengetahui: 1) Metode latihan sendiri memiliki pengaruh terhadap keterampilan pukulan forehand dalam permainan squash, 2) Metode latihan berpasangan memiliki pengaruh terhadap keterampilan pukulan forehand dalam permainan squash, 3) Metode latihan tiga orang memiliki pengaruh terhadap keterampilan pukulan forehand dalam permainan squash, dan 4) Perbedaan antara metode latihan sendiri, latihan berpasangan dan metode latihan tiga orang terhadap keterampilan pukulan forehand dalam permainan squash Mahasiswa FIK-UNM Makassar.

\section{Pustaka}

Olahraga Squash sebenarnya telah ada pada abad ke-19, di daerah Fleet Prison London. Menurut Hanlon (2009: 226) popularitas squash telah menyebar ke berbagai negara dan dimainkan di seluruh dunia oleh 15 juta orang, dengan lapangan squash di hampir setiap negara. Baru-baru ini permainan telah meningkat popularitasnya di Amerika Selatan, Eropa Timur, dan Amerika Serikat.

Meski terlahir dan besar di Inggris, namun justru Amerika Serikat yang pertama kali mendirikan asosiasi squash pada tahun 1907 dengan nama United States Squash Racquets Association. Padahal, di negeri asalnya Inggris squash pada awalnya merupakan cabang dari tenis lapangan. Squash baru berdiri sendiri di Inggris pada tahun 1928 dengan nama Squash Rackets Association. Sejak itu Inggris selalu menggelar turnamen squash dengan nama British Open. Inggris pulalah yang membawa olahraga tersebut ke seluruh pelosok dunia khususnya pada saat penjajahan. Tak heran lah jika negara jajahan Inggris yang tergabung dalam negara persemakmuran seperti Australia, Pakistan, Malaysia, Singapura lebih dulu menekuni squash dibanding Indonesia.

Di Indonesia sendiri, olahraga squash sebenarnya sudah dikenal sejak Perang Dunia II berakhir, tepatnya pada 1948. Tentara Inggris yang pertama kali membangun lapangan squash di Indonesia yang terletak di Embong Sawo Surabaya. Namun saat itu, hanya perwira berpangkat jenderal saja yang boleh memainkan olahraga tersebut. Bahkan sampai tahun 1978 hanya orang asing yang memainkan olahraga squash di Indonesia. Padahal saat itu lapangan squash sudah merupakan syarat mutlak untuk hotel-hotel berbintang di Indonesia. Pada tahun 1979, benang merah sejarah perkembangan squash mulai ditorehkan oleh seorang putra asli Indonesia yang bernama Bambang Gatot Subroto. Kala itu Bambang yang sering menyaksikan pertandingan squash karena ia bekerja di sebuah hotel berbintang di Jakarta ditawari mendalami squash di Pakistan. Kesempatan emas tersebut tidak disia-siakan oleh Bambang. Meski belum semahir legenda squash dunia asal Pakistan yang dikenal 
dengan 'Dinasti Khan' seperti Hashim Khan, Roshan Khan, Azam Khan, Mohibullah Khan, Jahangir Khan dan Jansher Khan yang secara turun-temurun bergiliran menjadi juara British Open mulai 1951 sampai 1994, akan tetapi Bambang sudah mampu mengalahkan Warga Negara Asing khususnya dari Eropa yang menginap di tempat ia bekerja. Padahal sebelumnya ia selalu dijadikan bulan-bulanan oleh para turis tersebut.

Dari semua keterampilan bermain squash, pukulan drive merupakan keterampilan yang paling penting yang harus dikuasai oleh setiap pemain squash, karena pukulan ini merupakan salah satu jenis pukulan yang paling sering digunakan oleh setiap pemain squash dalam berbagai level ketika bertanding. Menurut Yarrow (2010: 1), bahwa Forehand drive adalah pukulan yang dilakukan dari samping badan, dimana pemain memegang raket.

Pukulan drive ini dapat dilakukan dengan dua cara yaitu dengan forehand dan backhand. Dibandingkan dengan pukulan drive backhand, pukulan drive forehand merupakan pukulan yang cenderung lebih mudah untuk dilakukan para pemain squash pemula, bahkan bagi pemula yang sebelumnya tidak pernah memegang raket squash, mereka masih tetap mempunyai peluang yang besar untuk dapat memukul bola dengan menggunakan jenis pukulan drive forehand ini dengan kuat dan akurat. Banyak orang beranggapan bahwa melakukan pukulan pertama adalah dengan memukul bola cukup keras di sisi forehand. Tetapi menemukan akurasi yang diperlukan dalam pukulan forehand seringkali sulit dilakukan. Oleh karena itu sangat penting melatih atau mempelajari dasar-dasar pukulan forehand, baik berada di sisi belakang lapangan maupun sisi depan lapangan. Sedangkan untuk dapat menguasai pukulan drive backhand dengan baik, diperlukan proses latihan yang lebih lama.

Tidak seperti pukulan drive forehand, pukulan drive backhand merupakan pukulan yang kurang alamiah untuk dilakukan seorang pemain squash, pukulan ini harus lebih sering dipelajari. Namun demikian, pukulan drive backhand tetap merupakan pukulan yang penting untuk dikuasai sebagaimana halnya menguasai pukulan drive forehand. Pada waktu bermain, bola tidak selamanya datang ke sebelah kanan, untuk mengantisipasinya maka penguasaan pukulan backhand sangat penting agar mampu memainkan bola baik yang berada di sisi kiri maupun sisi kanan. Tidak hanya itu, pukulan drive backhand harus dilatih sedemikian rupa sampai terasa mudah melakukannya seperti halnya melakukan pukulan drive forehand. Karena dengan demikian, maka seorang pemain akan memungkinkan mampu memainkan pukulan dari berbagai sisi lapangan dengan baik pada setiap rally selama permainan berlangsung.

Kunci keberhasilan menguasai keterampilan pukulan forehand squash dengan baik dan benar dibutuhkan teknik atau cara memegang raket dengan tepat. Tanpa pegangan raket yang tepat akan mempengaruhi ayunan raket saat melakukan pukulan sehingga pantulan bola tidak dapat diarahkan dengan benar. Oleh karena itu, untuk menguasai keterampilan teknik pukulan forehand yang benar dengan mengikuti tahap-tahap yang diawali dengan posisi awal, pelaksanaan dan posisi 
akhir. Yarrow (2010: 2) menjelaskan teknik pegangan raket yang benar, yaitu genggam raket seperti berjabat tangan, jari telunjuk dan ibu jari membentuk huruf $\mathrm{V}$ yang terletak di tengah pegangan raket, jari tengah, jari manis dan kelingking menggenggam dengan baik, permukaan raket tetap terbuka.

Keterampilan merupakan gambaran tingkat kemampuan seseorang yang bervariasi pada satu tugas motorik dan gerakan yang dimaksud adalah kemampuan gerak (motorik) seseorang pada tingkatan tertentu.

Keterampilan yang dimiliki oleh seseorang diperoleh melalui proses pembelajaran, yang dimaksud adalah proses pembelajaran gerak. Belajar gerak merupakan sebagian dari belajar secara umum. Tujuannya adalah untuk menguasai berbagai keterampilan gerak dan mengembangkannya agar keterampilan gerak yang dikuasai bisa dilakukan untuk menyelesaikan tugas-tugas gerak dalam mencapai sasaran tertentu misalnya gerak olahraga. Dalam proses pembelajaran keterampilan gerak dosen/guru harus memahami tentang konsep dari belajar gerak itu sendiri. Pemahaman tentang belajar gerak akan memudahkan dosen atau guru untuk menyusun strategi pembalajaran gerak khususnya dalam. Pendidikan jasmani dan olahraga.

Coker (2004: 3) mengatakan bahwa belajar adalah perubahan yang relatif permanen dalam kemampuan seseorang untuk melaksanakan keterampilan motorik sebagai akibat dari praktek atau latihan. Schmidt (2008: 156) menjelaskan bahwa belajar hasil dari latihan atau pengalaman, Belajar tidak secara langsung diamati, perubahan belajar yang disimpulkan dari perubahan kinerja, pembelajaran melibatkan serangkaian proses dalam sistem saraf pusat, belajar menghasilkan kemampuan yang diperoleh untuk kinerja terampil, belajar perubahan relatif permanen, tidak transitory.

Metode latihan merupakan suatu pelajaran untuk mengembangkan latihan, dimana kata metode itu digunakan untuk kondisi materi kegiatan, Tangkudung (2012: 46). Latihan solo drill (praktek sendiri) adalah latihan untuk meningkatkan rangkaian pukulan atlet itu sendiri. Menambah pukulan yang baru dan mempraktekkan berbagai cara memukul bola.

Buttfield (1993: 7) mengungkapkan bahwa latihan forehand dapat dilakukan dengan latihan berpasangan. Latihan berpasangan merupakan suatu bentuk latihan yang sangat baik dan cenderung pada keaktifan dan kerjasama dua individu. Aip Syaifuddin (1994: 49) mengatakan bahwa kegiatan belajar secara berpasangan sangat baik diterapkan dalam keterampilan gerak yang memerlukan latihan secara berpasangan.

Buttfield (1993:9) mengungkapkan bahwa latihan forehand dapat dilakukan dengan latihan tiga orang. Dalam permainan squash, teknik pukulan forehand merupakan salah satu teknik dasar yang wajib dikuasai oleh seseorang yang ingin bermain squash. Karena teknik forehand memegang peranan penting dalam permainan. Teknik forehand merupakan salah satu teknik dasar yang multi fungsi. Karena dengan teknik forehand kita dapat melakukan pertahanan (defend) sekaligus merancang sebuah pola penyerangan (attack).

Berdasarkan penyusunan kerangka teoritik dan kerangka bepikir yang telah dikemukakan di atas, maka hipotesis penelitian dapat dirumuskan sebagai berikut: 1) 
Metode latihan sendiri memiliki pengaruh yang signifikan terhadap keterampilan pukulan forehand dalam permainan squash, 2) Metode latihan berpasangan memiliki pengaruh yang signifikan terhadap keterampilan pukulan forehand dalam permainan squash, 3) Metode latihan tiga orang memiliki pengaruh yang signifikan terhadap keterampilan pukulan forehand dalam permainan squash, dan 4) Terdapat perbedaan antara metode latihan sendiri, latihan berpasangan dan metode latihan tiga orang terhadap keterampilan pukulan forehand dalam permainan squash Mahasiswa FIKUNM Makassar.

\section{Metode}

Metode penelitian berhubungan erat dengan prosedur, teknik, alat serta desain penelitian yang digunakan. Desain penelitian harus cocok dengan pendekatan penelitian yang dipilih. Prosedur itu harus pula sesuai dengan metode penelitian yang ditetapkan. Sebelum penelitian yang dilaksanakan, peneliti perlu memperhatikan: (1) Urutan kerjaan atau prosedur yang harus dilaksanakan, (2) Alat-alat (instrument) yang akan digunakan dalam mengukur ataupun mengumpulkan data yang akan digunakan dalam menganalisis data, (3) Bagaimana pelaksanaan penelitian tersebut. Metode adalah suatu cara untuk mendapatkan kebenaran melalui pengamatan. Suryabrata (1988:9) mengartikan metode sebagai suatu cara untuk melakukan sesuatu. Di pihak lain Djaali (2010:1) menjelaskan, bahwa: Metode ilmiah adalah suatu prosedur dari proses mencari kebenaran, dengan langkah-langkah mengenal masalah dan merumuskannya, studi literatur, bila diperlukan merumuskan hipotesis, mengumpulkan dan mengolah data, menguji hipotesis dan mengambil kesimpulan. Metode yang akan digunakan dalam penelitian ini adalah metode eksperimental dengan desain Randomized Pre Test Post Tes three group design. Adapun rancangan penelitian dapat dilihat pada gambar berikut ini.

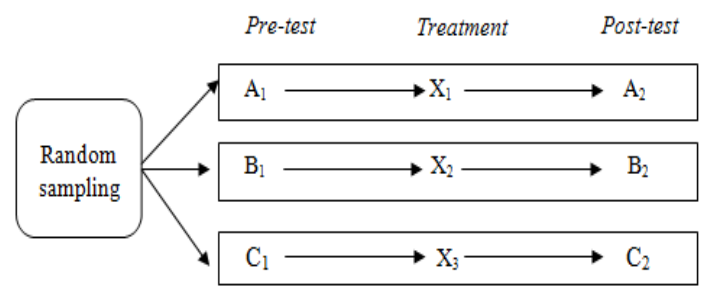

Gambar. 1. Desain Penelitian

(Randomized Pre Test Post Tes three group design)

Penelitian ini dilaksanakan di Lapangan Squash Kampus Banta-Bantaeng Fakultas Ilmu Keolahragaan Universitas Negeri Makassar dari bulan September sampai bulan oktober 2016. Waktu penelitian dilaksanakan pada tahap eksperimen selama 6 (enam) minggu atau 18 kali pertemuan. Setelah masa perlakuan selama 6 (enam) minggu, dilanjutkan dengan pengambilan data keterampilan pukulan forehand sebagai tes akhir. 
Teknik Pengumpulan Data dalam penelitian ini, Mahasiswa melakukan suatu gerakan pukulan forehand yang meliputi tiga dimensi, yaitu; (1) posisi awal, (2) pelaksanaan gerakan, (3) posisi akhir.

Teknik Analisis Data, data yang terkumpul melalui tes masih merupakan data kasar. Data tersebut selanjutnya di analisis dengan menggunakan uji statistik dengan bantuan program SPSS versi 23.00 .

Kesimpulan penelitian yang dikemukakan didasarkan pada hasil-hasil Uji-t, analisis t-test dalam pengujian hipotesis. Dikemukakan pula saran agar penelitian ini dimanfaatkan untuk meningkatkan keterampilan pukulan forehand dalam permainan squash mahasiswa FIK-UNM Makassar.

\section{Pembahasan}

Hasil penelitian ini menggunakan analisis Uji-t untuk menguji pengaruh perlakuan selama 18 kali pertemuan dengan perincian tiga kali seminggu metode latihan sendiri dan metode latihan berpasangan dan metode latihan tiga orang terhadap keterampilan pukulan forehand dalam permainan squash mahasiswa FIKUNM Makassar. Untuk lebih jelasnya dapat dilihat pada tabel 1 berikut:

\begin{tabular}{|c|c|c|c|c|c|}
\hline Variabel & Mean & $\mathbf{t}_{\text {-hitung }}$ & $t_{\text {tabel }}$ & Sig. & $\alpha$ \\
\hline pretest metode latihan sendiri & 24.31 & 81.283 & \multirow{6}{*}{2,042} & \multirow{6}{*}{0,000} & \multirow{6}{*}{0,05} \\
\hline Postest metode latihan sendiri & 25.02 & 76.964 & & & \\
\hline $\begin{array}{l}\text { pretest metode latihan } \\
\text { berpasangan }\end{array}$ & 22,93 & 55,882 & & & \\
\hline $\begin{array}{l}\text { Postest metode latihan } \\
\text { berpasangan }\end{array}$ & 23,07 & 72,173 & & & \\
\hline pretest metode latihan tiga orang & 21,48 & 57,766 & & & \\
\hline Postest metode latihan tiga orang & 22,06 & 63,192 & & & \\
\hline
\end{tabular}

Dari hasil analisis data mengggunakan uji-t pada tabel 1 diatas dapat disimpulkan bahwa masing - masing perlakuan baik sebelum dan sesudah perlakuan terdapat perbedaan yang singnifikan dengan tingakat kesalahan $\alpha=0,05$ dengan taraf signifikan 0,000 atau nilai probabilitas lebih kecil dari $\alpha=0,05(0,000<\alpha=0,05)$.

Selanjutnya untuk memperkuat pengujian uji-t dilanjutkan dengan analisis menggunakan uji post hoc multiple comparations dengan menggunakan analisis least significant diffrence (LSD) dalam program SPSS versi 23.00, sebagai upaya untuk melihat variabel independent mana yang memberikan pengaruh secara signifikan terhadap peningkatan variabel dependen. Hasil dari uji post hoc dengan LSD untuk variabel ketiga kelompok perlakuan untuk pretest dapat dilihat pada tabel 2 berikut: 
Tabel 2. Hasil Uji Post-Hoc dengan LSD tes awal metode latihan

\begin{tabular}{l|l|c|c|}
\hline \multicolumn{2}{|c|}{ Kelompok } & $\begin{array}{c}\text { Mean } \\
\text { difference }\end{array}$ & $\begin{array}{c}\text { Signifikansi } \\
\text { (p) }\end{array}$ \\
\hline $\begin{array}{l}\text { Pretest Metode latihan } \\
\text { sendiri }\end{array}$ & $\begin{array}{l}\text { Pretest Metode } \\
\text { latihan } \\
\text { berpasangan }\end{array}$ & 1,594 & 0,000 \\
\cline { 2 - 4 } & $\begin{array}{l}\text { Pretest Metode } \\
\text { latihan tiga orang }\end{array}$ & 2,969 & 0,000 \\
\hline $\begin{array}{l}\text { Pretest Metode latihan } \\
\text { berpasangan }\end{array}$ & $\begin{array}{l}\text { Pretest Metode } \\
\text { latihan tiga orang }\end{array}$ & 1,375 & 0,000 \\
\hline
\end{tabular}

Dari hasil analisis data mengggunakan uji post hoc multiple comparations dengan menggunakan analisis least significant diffrence (LSD) dalam program SPSS versi 23.00 pada tabel 2 diatas dapat disimpulkan bahwa masing - masing perlakuan baik sebelum perlakuan terdapat perbedaan yang singnifikan dengan tingakat kesalahan $\alpha=0,05$ dengan taraf signifikan 0,000 atau nilai probabilitas lebih kecil dari $\alpha=0,05(0,000<\alpha=0,05)$. Selanjutnya untuk hasil dari uji post hoc dengan LSD untuk variabel ketiga kelompok perlakuan untuk post-test dapat dilihat pada 3 berikut:

Table 3. Hasil Uji Post-Hoc dengan LSD tes akhir metode latihan

\begin{tabular}{|l|l|c|c|}
\hline \multicolumn{2}{|c|}{ Kelompok } & \multicolumn{1}{|c|}{$\begin{array}{c}\text { Mean } \\
\text { difference }\end{array}$} & $\begin{array}{c}\text { Signifikansi } \\
\text { (p) }\end{array}$ \\
\hline $\begin{array}{l}\text { Post-test Metode } \\
\text { latihan sendiri }\end{array}$ & $\begin{array}{l}\text { Post-test Metode } \\
\text { latihan } \\
\text { berpasangan }\end{array}$ & 1,938 & 0,000 \\
\cline { 2 - 5 } & $\begin{array}{l}\text { Post-test Metode } \\
\text { latihan tiga orang }\end{array}$ & 3,000 & 0,000 \\
\hline $\begin{array}{l}\text { Post-test Metode } \\
\text { latihan berpasangan }\end{array}$ & $\begin{array}{l}\text { Post-test Metode } \\
\text { latihan tiga orang }\end{array}$ & 1,063 & 0,000 \\
\hline
\end{tabular}

Dari hasil analisis data mengggunakan uji post hoc multiple comparations dengan menggunakan analisis least significant diffrence (LSD) dalam program SPSS versi 23.00 pada tabel 3 diatas dapat disimpulkan bahwa masing - masing perlakuan baik sesudah perlakuan terdapat perbedaan yang singnifikan dengan tingakat kesalahan $\alpha=0,05$ dengan taraf signifikan 0,000 atau nilai probabilitas lebih kecil dari $\alpha=0,05(0,000<\alpha=0,05)$.

Berdasarkan Hasil-hasil analisis statistik dalam pengujian hipotesis perlu dikaji lebih lanjut dengan memberikan interpretasi keadaan dan keterkaitan antara hasil analisis yang dicapai dengan teori-teori yang mendasari penelitian. Penjelasan ini diperlukan agar dapat diperoleh kesesuaian teori yang telah dikemukakan dengan hasil penelitian yang dicapai. Hasil-hasil yang dicapai dalam penelitian ini melalui analisis statistik sebagai berikut:

1. Ada pengaruh pretest dan post-test metode latihan sendiri terhadap keterampilan pukulan forehand dalam permainan squash mahasiswa FIK-UNM Makassar 
Ada pengaruh pengaruh yang signifikan metode latihan sendiri terhadap keterampilan pukulan forehand dalam permainan squash mahasiswa FIK-UNM Makassar berbeda. Sesuai hasil pretest dan postest dengan menggunakan uji-t metode latihan sendiri terhadap keterampilan pukulan forehand dalam permainan squash mahasiswa FIK-UNM Makassar, diperoleh masing - masing nilai $t_{\text {-hitung }}=81,283$ dan $76,964>\mathrm{t}$-tabel 2,042 (nilai sig. $0,000<\alpha 0,05$ ), berarti ada perbedaan pengaruh dari pretest dan postest perlakuan metode latihan sendiri yang signifikan. Untuk membuktikan peningkatan keterampilan pukulan forehand dalam permainan squash ini dibuktikan dengan perbedaan nilai rata-rata untuk pretest sebesar 24,31 dan posttest sebesar 25,02 hal ini terdapat peningkatan nilai rata - rata sebesar 0,71 metode latihan sendiri mahasiswa FIK-UNM Makassar atau dengan kata lain hasil

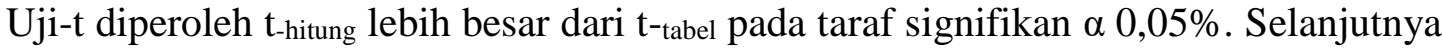
dilihat dari nilai rata-rata keterampilan pukulan forehand dalam permainan squash mahasiswa FIK-UNM Makassar. Berdasarkan hasil analisis data, maka dapat dikatakan bahwa ada perbedaan yang signifikan nilai rata-rata keterampilan pukulan forehand dalam permainan squash mahasiswa FIK-UNM Makassar.

Berdasarkan kajian teori dan fakta yang ada, dapat dikemukakan bahwa pemberian latihan sendiri secara terprogram dengan sistematis, frekwensi latihan 3 (tiga) kali seminggu dengan durasi waktu 90 menit persatu kali latihan. Latihan sendiri adalah bentuk latihan yang dilakukan secara individu. Pemain melakukan latihan ini dengan cara berdiri kurang lebih satu meter di bagian lapangan dinding depan sebelah kanan. Kemudian dengan melakukan pukulan forehand dan secara bertahap apabila sudah menguasai pukulan ini, pemain mundur selangkah sambil tetap memantulkan bola ke dinding depan. Latihan ini dilakukan terus-menerus sampai pemain berada di bagian belakang lapangan sebelah kanan dan berhenti kira-kira kurang lebih satu meter dinding belakang. Dengan latihan ini pemain dapat mengontrol kekuatan pukulan dan arah bola sehingga lebih mudah dan cepat menguasai teknik pukulan forehand.

2. Ada pengaruh pretest dan post-test metode latihan berpasangan terhadap keterampilan pukulan forehand dalam permainan squash mahasiswa FIK-UNM Makassar

Ada pengaruh pengaruh yang signifikan metode latihan berpasangan terhadap keterampilan pukulan forehand dalam permainan squash mahasiswa FIK-UNM Makassar berbeda. Sesuai hasil uji beda pretest dan postest dengan menggunakan uji$\mathrm{t}$ metode latihan berpasangan terhadap keterampilan pukulan forehand dalam permainan squash mahasiswa FIK-UNM Makassar, diperoleh masing - masing nilai $\mathrm{t}_{\text {-hitung }}=55,882$ dan 72,173 $>\mathrm{t}$-tabel 2,042 (nilai sig. 0,000 $<\alpha 0,05$ ), berarti ada perbedaan pengaruh dari pretest dan postest perlakuan metode latihan berpasangan yang signifikan. Untuk membuktikan peningkatan keterampilan pukulan forehand dalam permainan squash ini dibuktikan dengan perbedaan nilai rata-rata untuk pretest sebesar 22,93 dan posttest sebesar 23,07 hal ini terdapat peningkatan nilai rata - rata sebesar 0,14 metode latihan berpasangan mahasiswa FIK-UNM Makassar. Atau dengan kata lain hasil Uji-t diperoleh t-hitung lebih besar dari $t$-tabel pada taraf 
signifikan $\alpha 0,05 \%$. Selanjutnya dilihat dari nilai rata-rata keterampilan pukulan forehand dalam permainan squash mahasiswa FIK-UNM Makassar. Berdasarkan hasil analisis data, maka dapat dikatakan bahwa ada perbedaan yang signifikan nilai rata-rata keterampilan pukulan forehand dalam permainan squash mahasiswa FIKUNM Makassar.

Latihan berpasangan adalah bentuk latihan yang dilakukan dua orang pemain dengan melakukan pukulan forehand ke dinding depan secara bergantian. Bisa dimulai dari depan lalu ke tengah dan sampai ke belakang daerah lapangan squash. Latihan ini sangat bermanfaat dalam menunjang perkembangan bermain baik dari segi teknik maupun penguasaan gerakan di lapangan karena latihan seperti inilah yang terjadi di lapangan pada saat bertanding.

3. Ada pengaruh pretest dan post-test metode latihan metode latihan tiga orang terhadap keterampilan pukulan forehand dalam permainan squash mahasiswa FIK-UNM Makassar

Ada pengaruh pengaruh yang signifikan metode latihan tiga orang terhadap keterampilan pukulan forehand dalam permainan squash mahasiswa FIK-UNM Makassar berbeda. Sesuai uji beda pretest dan postest dengan menggunakan uji-t metode latihan metode latihan tiga orang terhadap keterampilan pukulan forehand dalam permainan squash mahasiswa FIK-UNM Makassar, diperoleh masing - masing nilai $\mathrm{t}_{\text {-hitung }}=21,48$ dan 22,06 $>\mathrm{t}$-tabel 2,042 (nilai sig. 0,000< 00,05 ), berarti ada perbedaan pengaruh dari pretest dan postest perlakuan metode latihan sendiri yang signifikan. Untuk membuktikan peningkatan keterampilan pukulan forehand dalam permainan squash ini dibuktikan dengan perbedaan nilai rata-rata untuk pretest sebesar 21,48 dan posttest sebesar 22,06 hal ini terdapat peningkatan nilai rata - rata sebesar 0,72 metode latihan sendiri mahasiswa FIK-UNM Makassar. atau dengan kata lain hasil Uji-t diperoleh t-hitung lebih besar dari t-tabel pada taraf signifikan $\alpha$ $0,05 \%$. Selanjutnya dilihat dari nilai rata-rata keterampilan pukulan forehand dalam permainan squash mahasiswa FIK-UNM Makassar. Berdasarkan hasil analisis data, maka dapat dikatakan bahwa ada perbedaan yang signifikan nilai rata-rata keterampilan pukulan forehand dalam permainan squash mahasiswa FIK-UNM Makassar.

Metode latihan tiga orang merupakan bentuk latihan yang dilakukan oleh pemain yang berjumlah tiga orang. Teknik berlatih tiga orang yaitu satu pemain berada di daerah belakang lapangan sebelah kanan dan memberikan umpan kepada dua orang yang berada di sebelah kiri lapangan. Kedua pemain yang berada di sebelah kiri lapangan secara bergantian memukul dan mengarahkan bola kembali ke arah sebelah kanan. Terdapat kekurangan dalam metode latihan tiga orang ini, karena pemain yang akan memukul bola harus bergatian dan tidak menutup kemungkinan para pemain saling bertabrakan 
4. Ada perbedaan pengaruh post-test metode latihan sendiri dan metode latihan berpasangan terhadap keterampilan pukulan forehand dalam permainan squash mahasiswa FIK-UNM Makassar

Ada pengaruh pengaruh yang signifikan metode latihan sendiri, metode latihan berpasangan dan metode latihan tiga orang terhadap keterampilan pukulan forehand dalam permainan squash mahasiswa FIK-UNM Makassar berbeda. Adanya perbedaan yang signifikan diantara ketiga kelompok. Perbedaan tersebut dapat dilihat dari mean difference. Sehingga dari mean difference tersebut memberikan sebuah makna bahwa data tes awal perbedaan pengaruh metode latihan terhadap keterampilan pukulan forehand dalam permainan squash mahasiswa FIK-UNM Makassar antar kelompok penelitian. Hal ini dapat diketahui dari nilai mean difference, bahwa kelompok metode latihan sendiri sebelum perlakuan lebih optimal peningkatan keterampilan pukulan forehand dalam permainan squash dibandingkan dengan kelompok metode latihan berpasangan maupun metode latihan tiga orang. Demikian pula pada tes akhir metode latihan menunjukkan bahwa kelompok metode latihan sendiri lebih optimal dibanding kelompok yang lain, Selanjutnya dilihat dari nilai rata-rata keterampilan pukulan forehand dalam permainan squash mahasiswa FIK-UNM Makassar. Berdasarkan hasil analisis data, maka dapat dikatakan bahwa ada perbedaan yang signifikan nilai rata-rata keterampilan pukulan forehand dalam permainan squash mahasiswa FIK-UNM Makassar.

Selanjutnya ada perbedaan signifikan diantara ketiga kelompok. Perbedaan tersebut dapat dilihat pada mean difference, sehingga dari perbedaan tersebut memberikan sebuah makna memberikan sebuah makna bahwa data tes akhir perbedaan pengaruh metode latihan terhadap keterampilan pukulan forehand dalam permainan squash mahasiswa FIK-UNM Makassar antar kelompok penelitian. Hal ini dapat diketahui dari nilai mean difference, bahwa kelompok metode latihan sendiri sebelum perlakuan lebih optimal peningkatan keterampilan pukulan forehand dalam permainan squash dibandingkan dengan kelompok metode latihan berpasangan maupun metode latihan tiga orang.

\section{Simpulan}

Berdasarkan hasil analisis statistik infrensial, dan hasil analisis Uji-t dalam pengujian hipotesis, maka hasil penelitian ini disimpulkan sebagai berikut:

1. Metode latihan sendiri memiliki pengaruh terhadap keterampilan pukulan forehand dalam permainan squash Mahasiswa FIK-UNM Makassar.

2. Metode latihan berpasangan memiliki pengaruh terhadap keterampilan pukulan forehand dalam permainan squash Mahasiswa FIK-UNM Makassar.

3. Metode latihan tiga orang memiliki pengaruh terhadap keterampilan pukulan forehand dalam permainan squash Mahasiswa FIK-UNM Makassar.

Terdapat perbedaan antara metode latihan sendiri, latihan berpasangan dan metode latihan tiga orang terhadap keterampilan pukulan forehand dalam permainan squash Mahasiswa FIK-UNM Makassar. 


\section{Rujukan}

Buttfiel Kim., Let's Drill. Squash drill and exercise to improve your game. Australia:Action Press, 1993.

Coker Cheryl A., Motor Learning And Control for Practitioner. New Mexico McGraw Hill, 2004.

Djaali., Konsep Dasar dan Pokok-Pokok Desain Eksperimen. Jakarta: PPs UNJ, 2010.

Hanlon Thomas., The Sports Rules Book. Champaign: Human Kinetics Publisher.,2009.

Hirst A Peter., Squash: Skills, Teckniques, Tactics. British: The Crowood Press Ltd., 2014.

Kindersley Dorling., The Sports Book. London, New York, Munich, Melbourne, and Delhi: Published in the United States by DK Publishing, 2013.

---------,http://ggo-blog.blogspot.com/2013/11/ sejarah-dan-cara-bermainsquash.html.

---------,http://ggo-blog.blogspot.com/2013/11/ sejarah-dan-cara-bermainsquash.html

Schmidt Richard A., Motor Learning and Performance. Champaign: Human Kinetics, 2008.

Suryabrata Sumadi., Metodologi Penelitian. Jakarta: CV Rajawali, 1988.

Syaifuddin Aip., Dasar-dasar Dalam Proses Belajar Mengajar Pendidikan Jasmani. Jakarta: FPOK IKIP, 1994.

Tangkudung James., Kepelatihan Olahraga, Pembinaan Prestasi Olahraga. Jakarta: Cerdas Jaya 2012.

Yarrow Philip, Harrison Aidan., Squash Steps to Success. Champaign: Human Kinetics Publisher Inc., 2010. 